\title{
10
}

\section{Choices: Future Trade-Offs and Plausible Pathways}

\author{
Attila N. Lázár, Susan E. Hanson, Robert J. Nicholls, \\ Andrew Allan, Craig W. Hutton, Mashfiqus Salehin \\ and Abiy S. Kebede
}

\subsection{Introduction}

Human-dominated deltas are hotspots of high population density, economic development and ecosystem service value that are concurrently subject to natural and anthropogenic pressures and changes. The integrity of deltas, as coupled human and natural systems, is fundamentally

A. N. Lázár ( $凹)$ · S. E. Hanson · R. J. Nicholls · A. S. Kebede School of Engineering, University of Southampton, Southampton, UK e-mail: a.lazar@soton.ac.uk

A. Allan

School of Law, University of Dundee, Dundee, UK

C. W. Hutton

GeoData Institute, Geography and Environmental Science, University of Southampton, Southampton, UK

M. Salehin

Institute of Water and Flood Management, Bangladesh University of Engineering and Technology, Dhaka, Bangladesh 
integrated with their hydrodynamic processes and in particular the provision of sediments (see Chapters 5 and 6). A natural delta adjusts its form and function in balance with such processes (Wolman and Gerson 1978), but Anthropocene deltas are more defined by the intimate relationship between humans and their physical systems (see Day et al. 2016). Human settlements and economies manipulate the natural circumstances in the delta for their benefit, but when such efforts occur on the catchment scale, this permanently alters the trends and balance of the whole system (Overeem and Syvitski 2009).

Contemporary trends and changes inevitably lead to trade-offs between the needs of diverse populations of people and the requirements to maintain a sustainable, productive environment and associated services (Steffan-Dewenter et al. 2007; Hutton et al. 2018). For example, to accept annual floods would be beneficial for maintaining long-term land elevation, soil fertility and local ecosystems (Chapter 5). However, benefits of incorporating natural processes into already engineered delta systems come with the cost of potential flood damage to infrastructures, people and agriculture. Other trade-offs are between development and nature at various scales. Land transformations to aquaculture in brackish conditions, for example, results in soil and biodiversity degradation and decline in local agriculture balanced against economic needs at a national level (Amoako-Johnson et al. 2016). However, populations are not static, adapting and evolving temporally and spatially within the Anthropocene (as discussed in Chapters 7 and 9). Indeed, individual households and communities adapt to changing circumstances, in effect making tradeoffs at community and household level. Both natural resource-based and off-farm households constantly adapt due to a range of reasons including environmental pressures and economic opportunities.

Policies aiming to promote particular human benefits can also often generate diverse and unforeseen trade-offs at the government, community or individual level, and over short- or long-term timescales. Focussing on identifying, understanding and quantifying such tradeoffs enables governments, planners and civil society to accomplish their national aims while supporting delta populations in their development.

In this chapter therefore, choices, potential trade-offs and plausible pathways for Anthropocene deltas are explored, drawing fundamentally 
on integrated modelling and other simulation approaches. Tradeoffs from coastal Bangladesh in the Ganges-Brahmaputra-Meghna (GBM) Delta in particular are outlined to illustrate environmental and socio-economic trends, potential trade-offs and local adaptation options as a result of high-level policy decisions. The analysis includes actions and dilemmas faced by individuals, referred to as household adaptation (see Chapter 9) across the three deltas considered in Chapters 2-4. This analysis is used to reflect on delta management across the world and how analysis of trade-offs can be used to address future development trajectories.

\subsection{Policy Development in Deltas}

A trade-off is "a situation where one balances two opposing situations or qualities", which inherently means that "one accepts something bad in order to have something good" (Online Cambridge Dictionary). Understanding trade-offs is especially crucial for deltas as their entire extent and existence are uniquely vulnerable to decisions made at national, local and household levels. Broader governance frameworks across a range of scales need to consider exogenous and endogenous factors over the delta and its catchment in determining how multiple interests can be weighed over time and space.

Governance frameworks and regimes serve at least in part to facilitate the balancing the needs of sectors, interests and regions (Paavola et al. 2009). Higher quality systems are able to maximise the accountability of those making and implementing decisions and hopefully ensure that, while decisions will inevitably be taken in the absence of perfect information, appropriate adaptation is possible. Coordination and integration of policymaking across sectors and space are critical for minimising potential negative effects. For example, integration potentially ensures that disaster risk management at the local level is aligned with national and regional mechanisms (Allan 2017), but also across civil emergencies, infrastructure maintenance and human rights (APFM 2006). Such coordination is challenging but essential if trade-offs are to reflect the relative values of each element. 
Physical and administrative boundaries rarely coincide for deltas. Thus, decisions made outside, or in different areas of, the delta may have disproportionate effects (see, for example, the impact of dams on sediment transport in Chapter 6). Policymaking and the relevant legal architecture in relation to the management of water resources and floods, for example the European Water Framework Directive (Article 3, European Parliament and Council 2000), generally express balance between upstream and downstream rights and interests. More specifically, delta nations such as the Netherlands, Vietnam and Bangladesh, have international agreements in place that make their planning processes more robust and flexible (Seijger et al. 2017). However, in most cases, this does not happen (for example, India), as there is no agreement at basin level on how the river is to be managed (Global Water Partnership 2000). This has the effect of limiting or skewing the trade-offs and reducing options that can be considered. Lack of data-sharing mechanisms and limitations on basin management, whether at national or international scales, may result in a similar situation (Gerlak et al. 2011).

Trade-offs that maximise benefits and minimise disadvantages would appear to be desirable. But governments typically do not have complete autonomy in decision-making, and are constrained by international obligations. For example, the rights of co-riparian states under international law relating to transboundary waters (United Nations 1997), the rights of women (United Nations 1966), the views of relevant stakeholders (UNECE 1998), protection of the environment (e.g. Ramsar 1971) and human rights more generally. Such international frameworks also inform those making policy regarding deltas about best practice. The Sendai Framework on Disaster Risk Reduction (United Nations 2015) for example, illuminates how trade-offs can be put into effect. Human rights considerations have broader impacts for policymaking and the assessment of trade-offs as they may oblige policymakers to make public the considerations that have not only been considered in policy development and implementation, but more importantly to define those people who have rights to be involved in the making of those policies. For deltas in particular, consideration of the aims, obligations and challenges of global issues, such as climate change, can also affect decision-making (Hoegh-Guldberg et al. 2018). 
In the end, governments that are seeking to develop policy for deltas and their inhabitants will be framed, informed and unavoidably influenced by factors over which they may have little control. However, delta planning processes, principally affecting flood and water management infrastructure, remain likely to be more effective if they are nested within flood and water resource management governance which extends across whole basins.

\subsection{Assessing Trends and Trade-Offs Under Plausible Delta Futures}

Trends and trade-offs are, it is suggested, symptomatic of delta development during the Anthropocene. Hence their identification and evaluation play an important role in understanding the future of deltas thus enabling evidence-based decision-making and planning (Anderies et al. 2007; Daw et al. 2016). Integrated Assessment Modelling captures the main elements and characteristics of the system in a framework and allows the testing of a range of scenarios. Trade-offs are identified by comparing scenarios and identifying the winners and losers of the changes (Daw et al. 2011; Chapman and Darby 2016). Thus, integrated modelling can help to identify plausible trends, and locate, estimate and highlight the risks or benefits (including previously unforeseen) associated with proposed or unintended changes for future delta development.

Here a novel integrated assessment model, the Delta Dynamic Integrated Emulator model $(\triangle D I E M)$ is used. Originally developed for coastal Bangladesh in the GBM Delta (Nicholls et al. 2018), it allows the exploration of the interactive relationships between natural and socio-economic processes under a range of scenarios and policy options to identify both trends and trade-offs (Nicholls et al. 2016; Hutton et al. 2018; Lázár et al. 2018b). The following sections illustrate tradeoffs using different approaches and scenarios in each case; please note that comparison between examples is therefore not possible.

Within $\triangle \mathrm{DIEM}$, contrasting scenarios can be constructed from the model variables to explore the effects on the well-being of the local population and productivity. Table 10.1 shows the main components 
Table 10.1 Summary of assumed changes from present (2015) to 2100 for coastal Bangladesh within the two selected scenarios

\begin{tabular}{|c|c|c|}
\hline & \multicolumn{2}{|l|}{ Scenario descriptions } \\
\hline & Positive world & Negative world \\
\hline Sea-level rise & $\begin{array}{l}\text { Slow- } 54 \mathrm{~cm}(26 \mathrm{~cm} \text { in } \\
2050)\end{array}$ & Fast $-148 \mathrm{~cm}(61 \mathrm{~cm}$ in 2050$)$ \\
\hline Air temperature & $+3.7^{\circ} \mathrm{C}$ & $+4.1^{\circ} \mathrm{C}$ \\
\hline Other climate & $\begin{array}{l}\text { Moderately drier } \\
\text { climate }(-15 \% \\
\text { annual precipitation } \\
\text { compared to mean } \\
\text { of } 2000-2015 ;-17 \% \\
\text { total monsoon rain } \\
\text { and }-3 \% \text { total dry } \\
\text { season rainfall) }\end{array}$ & $\begin{array}{l}\text { Wetter climate }(+10 \% \text { annual } \\
\text { precipitation compared to } \\
\text { mean of } 2000-2015) \text { with more } \\
\text { extremes: wetter monsoon } \\
(+2 \%) \text { and drier dry seasons } \\
(-18 \%)\end{array}$ \\
\hline Population & $\begin{array}{l}\text { Maintained at } 14 \\
\text { million }\end{array}$ & $\begin{array}{l}\text { Decreasing to seven million, } \\
\text { reflecting net outmigration }\end{array}$ \\
\hline $\begin{array}{l}\text { Embankment } \\
\text { maintenance }\end{array}$ & $\begin{array}{l}\text { Good mainte- } \\
\text { nance-maintained } \\
\text { embankments }\end{array}$ & $\begin{array}{l}\text { Poor maintenance-slow } \\
\text { deterioration in embankment } \\
\text { height }(-3 \mathrm{~cm} \text { per year) }\end{array}$ \\
\hline $\begin{array}{l}\text { Farming and } \\
\text { agriculture }\end{array}$ & $\begin{array}{l}\text { New crop types } \\
\text { increase production } \\
(+20 \%)\end{array}$ & $\begin{array}{l}\text { Traditional crop types, no growth } \\
\text { in production }\end{array}$ \\
\hline $\begin{array}{l}\text { Manufacturing and } \\
\text { services }\end{array}$ & $\begin{array}{l}\text { Fast growth }(212 \% \\
\text { by } 2100 \text { or } 2.5 \% \text { per } \\
\text { year })\end{array}$ & $\begin{array}{l}\text { Slow growth ( } 53 \% \text { by } 2100 \text { or } \\
0.62 \% \text { per year) }\end{array}$ \\
\hline
\end{tabular}

of two extreme scenarios used to examine potential trends in coastal Bangladesh within the GBM Delta.

Figure 10.1 compares the expected trends for six indicators over this century associated with the selected scenarios. It is clear that each scenario has both positive and negative effects. For example, using the end numbers of the scenario configurations identified above, embankment deterioration, higher sea-level rise and more seasonality in river flows, the total inundated area increases by approximately $70 \%$ under the Negative scenario. In the alternative future with fewer extremes and better water resources management, the total inundation area does not change significantly.

There are environmental trade-offs in both worlds. In the Positive scenario, less flooding increases the soil salinity by about $30 \%$, due to 


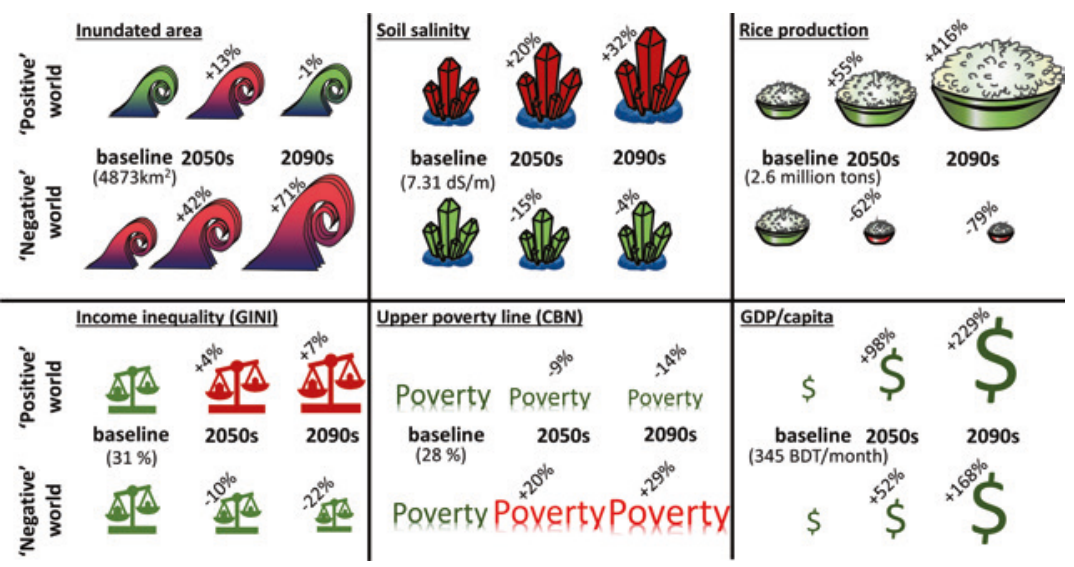

Fig. 10.1 Contrasting trends for coastal Bangladesh between the 'negative' and 'positive' scenarios (baseline: mean of 2005-2015)

less flushing effects, but this is compensated with salt tolerant crops and better management techniques, resulting in a fourfold net increase in rice productivity. Thus, food security and economy are not impacted, but environmental quality is degraded. In the opposite, Negative world, soil salinity slightly decreases due to the annual monsoon flushing of the salt out of soil. However, rice production collapses by about $80 \%$ due to the frequent flood damage, elevated temperature limitations and lower potential yields of traditional rice varieties compared to higher yielding varieties of the Positive world. Also, while environmental quality improves with more sediment deposition and lower salinity levels under the Negative world, traditional farming practices could have negative implications on the local economy. Of course, there are plausible futures which sit between these scenarios and these can be explored by the use of the modelling.

There are similar contradictions within and between income and inequality trends. Most noteworthy is that while GDP per capita increases significantly in the Positive world so does inequality indicating that the income gap within society widens. This increase in inequality lies in unequal land sizes and off-farm capital investments. The more land one owns, the more profit it makes under good economic conditions, 
whereas the economic growth of the poor and landless is slower. Hence the income gap widens. Income inequality is significantly lower in the Negative world where a lower per capita growth is experienced, but it is more equitably distributed. When the simulated household consumption rates are compared with the extrapolated trend of the upper poverty line of Bangladesh (BBS 2011), an increasing percentage of the Negative world population remains classified as in poverty. This indicates that poverty can persist even when the GDP per capita growth occurs, particularly where manufacturing and services form an important aspect of the local economy. Thus, targeted policies and development programs are required to provide a safety net and support for the poorest households and regions in any of the futures.

\subsection{Policy Driven Trade-Offs}

Variations in potential futures can also be strongly related to governance decisions and policy focus. Policy is generally set in relation to a single issue with little capacity for consideration of potential side effects or trade-offs with other sectors of society. This section presents a comparison of the effects of three contrasting policy examples (Table 10.2) with an Economic Development, a Social Welfare and an Environmental Sustainability focus against a baseline scenario describing a continuation of current trends. The Economic Development policy focuses on promoting productivity. Agriculture is promoted with progressively improving crop varieties. Irrigation use, irrigation efficiency and fertiliser use are also maximised. Fishing intensity is increased to get more economic benefits. Embankments are maintained to reduce the possibility of flooding. Population numbers are the same as the baseline scenario. For the Social Welfare policy, selected options aim to support households residing in the delta. The population remains at 14 million assuming that as a result of the policies net outmigration is zero. Agriculture retains the use of existing irrigation and fertiliser practices, and utilises new crops following research and development activities after 2050 to maximise income. In addition, agriculture costs are subsidised (25\%) and household expenses are reduced by $25 \%$ 
Table 10.2 Scenario summary of the policy trade-off simulations (by 2100). Cells with shading highlights the deviation from the Baseline scenario assumptions

\begin{tabular}{|c|c|c|c|c|}
\hline & $\begin{array}{c}\text { Baseline } \\
\text { (current trends) }\end{array}$ & $\begin{array}{c}\text { Economic } \\
\text { development }\end{array}$ & Social welfare & $\begin{array}{l}\text { Environmental } \\
\text { sustainability }\end{array}$ \\
\hline Climate & \multicolumn{4}{|c|}{ A warmer $\left(+3.7^{\circ} \mathrm{C}\right)$ and moderately drier ( $-13 \%$ precipitation) climate } \\
\hline Sea-level rise & \multicolumn{4}{|l|}{ Fast $-148 \mathrm{~cm}$ by 2100} \\
\hline Polders & \multicolumn{3}{|l|}{ Maintained existing } & $\begin{array}{l}\text { Deteriorate } \\
(-3 \mathrm{~cm} / \mathrm{yr})\end{array}$ \\
\hline $\begin{array}{l}\text { Tidal river } \\
\text { management }\end{array}$ & \multicolumn{3}{|l|}{ No } & $\begin{array}{l}\text { Yes ( } 2020 \text { for } 5 \text { years; } \\
\text { all polders) }\end{array}$ \\
\hline Population & $\begin{array}{l}\text { Decreasing to } 10 \\
\text { million }\end{array}$ & $\begin{array}{l}\text { Decreasing to } 10 \\
\text { million }\end{array}$ & $\begin{array}{l}\text { Maintained at } 14 \\
\text { million }\end{array}$ & $\begin{array}{l}\text { Decreasing to } 7 \\
\text { million }\end{array}$ \\
\hline Land cover & $\begin{array}{l}\text { Present land cover, } \\
\text { slightly increasing } \\
\text { agriculture at the } \\
\text { expense of } \\
\text { mangroves }\end{array}$ & $\begin{array}{l}\text { Better zoning in land } \\
\text { use, slight decrease } \\
\text { in agriculture, but } \\
\text { increasing } \\
\text { urbanisation }\end{array}$ & $\begin{array}{l}\text { Present land cover, } \\
\text { slightly increasing } \\
\text { agriculture at the } \\
\text { expense of } \\
\text { mangroves }\end{array}$ & $\begin{array}{l}\text { Better zoning in land } \\
\text { use, slight decrease } \\
\text { in agriculture, but } \\
\text { increasing } \\
\text { urbanisation }\end{array}$ \\
\hline Economy & $\begin{array}{l}\text { Moderate growth } \\
\text { (off-farm: } 106 \% \text {, } \\
\text { ES-based: } 53 \% \text { ) }\end{array}$ & $\begin{array}{l}\text { Fast growth (off- } \\
\text { farm: } 212 \%, \text { ES- } \\
\text { based: } 106 \% \text { ) }\end{array}$ & $\begin{array}{l}\text { Moderate growth } \\
\text { (off-farm: } 106 \% \text {, ES- } \\
\text { based: } 53 \% \text { ) } \\
\text { BUT lower house- } \\
\text { hold costs (-25\%) }\end{array}$ & $\begin{array}{l}\text { Moderate growth } \\
\text { (off-farm: } 106 \% \text {, ES- } \\
\text { based: } 53 \% \text { ) }\end{array}$ \\
\hline Subsidies & No & No & $\begin{array}{l}\text { Agriculture costs (- } \\
25 \%)\end{array}$ & No \\
\hline Agriculture crops & Present day crops & $\begin{array}{l}\text { new crop types } \\
\text { increased production } \\
(+20 \%)\end{array}$ & Present day crops & $\begin{array}{l}\text { Traditional crop } \\
\text { types, no growth in } \\
\text { production }\end{array}$ \\
\hline Irrigation & Present practices & everywhere & Present practices & No irrigation \\
\hline $\begin{array}{l}\text { Irrigation } \\
\text { efficiency }\end{array}$ & $90 \%$ & $100 \%$ & $90 \%$ & $\mathrm{n} / \mathrm{a}$ \\
\hline Fertiliser use & Present practices & Present practices & Present practices & No fertiliser \\
\hline Fishing intensity & $\begin{array}{l}\text { Twice the } \\
\text { sustainable level }\end{array}$ & $\begin{array}{l}\text { Four times the } \\
\text { sustainable level }\end{array}$ & Sustainable level & Sustainable level \\
\hline
\end{tabular}

throughout the simulations to relieve the households financially and make life easier, so that they do not migrate away. Fishing intensity is reduced to provide a long-term sustainable fishing income. Under the Environmental Sustainability policy, the aim is to restore as far as possible the natural condition of the delta. The dyke system is allowed to 
slowly deteriorate over this century increasingly allowing flooding, and thus increasing sedimentation. In addition, Tidal River Management for all polders during the 2020s enable sediment accumulation: further interventions are not needed as flooding and thus sedimentation will intensify over time as embankments deteriorate. Farming practices go back to traditional crops and methods and do not use irrigation or fertiliser. Fishing intensity is reduced to a sustainable level. Population numbers fall to seven million by the end of the century. The specific options selected within $\triangle \mathrm{DIEM}$ for each policy are summarised in Table 10.2; climate and sea-level scenarios remain constant.

The potential trade-offs are shown as the percentage of difference for six selected indicators when compared to the Baseline scenario. The results are surprising (Fig. 10.2). By 2050, the changes compared to Baseline are relatively small. Soil salinity is drastically reduced under the Environmental Sustainability scenario as a result of the deteriorating embankments and thus more frequent flooding and monsoon flushing of salt from the soil. However, soil salinity trends will not change as a result of the other scenarios. Rice productivity is maintained when the irrigation is maximised, but in all other cases, the productivity will fall. Returning to traditional farming practices would leave the region with about $70 \%$ less rice. Income inequality (GINI index) is not impacted

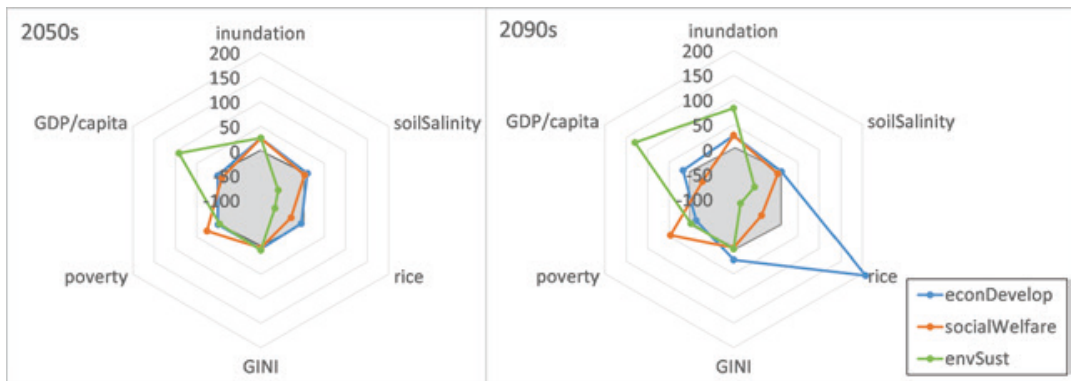

Fig. 10.2 Trade-offs resulting from different policy focuses in coastal Bangladesh. The values show the relative change (percent) compared to the baseline simulation (i.e. current trends). The grey shaded area indicates negative change 
significantly by these governance changes. Poverty however, would increase under the Social Welfare scenario $(+25 \%)$. Finally, GDP per capita would sharply increase under the Environmental Sustainability scenario $(+90 \%)$.

By the end of the century, these trends are amplified. Flooding intensifies under the Environmental Sustainability scenario due to the disappearance of the dyke system in coastal Bangladesh. The soil salinity does not deviate further from the Baseline. However, rice productivity multiplies under the Economic Development scenario (+200\%) and falls to an even lower level under the Environmental Sustainability scenario $(-80 \%)$. Inequality increases under the Economic Development scenario $(+20 \%)$, but poverty is reduced under the same scenario by ten percent. However, poverty increases under the Social Welfare scenario by approximately $50 \%$ (compared to Baseline). As a result of this poverty increase, GDP/capita falls under the Social Welfare scenario, but increases under Economic Development $(-20 \%)$ and Environmental Sustainability (130\%).

The results described above provide somewhat counter-intuitive results to conventional wisdom concerning the outcome of policy strategies. Why would the Social Welfare scenario result in higher poverty rates and why would the Environmental Sustainability scenario generate higher GDP per capita results than the Economic Development scenario? Based on the model results, a key factor lies in the assumptions about population. The Environmental Sustainability scenario assumes a rapidly declining population and a land redistribution. This means that as the population size decreases, the remaining farmers would accumulate more productive land and farm size increases through land consolidation. Thus, even though the rice productivity is drastically reduced, larger farm sizes compensate for the loss of yield resulting in a higher GDP per capita value. The scenario also has better biodiversity as a result of the reconnected land to river, lower soil salinity and sustainable fishing habits. However, more frequent and extensive flooding can be expected.

The Economic Development scenario solely focuses on economic gains, thus exploiting the environment with higher fishing efforts and 
more intrusive farming practices. Rice productivity increases significantly, but population size remains the same as in the Baseline. This results in only a moderate increase in GDP per capita, as the share from this significant increase in productivity mainly benefits the large landowners. As a result, poverty slightly decreases, but inequality noticeably increases by the end of the century.

At the heart of the Social Welfare scenario is the aim to support rural livelihoods and welfare through subsidies on household expenses and agriculture costs. However, this aim is not achieved in the simulation. The population size remains at today's level, but this results in smaller farm sizes. Rice productivity declines slightly due to slightly increased flooding and the new subsidies are not sufficient to compensate for the loss in income and small farm size. Since more landless and small landowners remain, the overall poverty rate increases and the GDP per capita falls. Thus, investment in social capital and land consolidation seem to be key to make the coastal zone socio-economically more sustainable. Of course, in undesirable circumstances, there is likely to be an increase in migratory behaviour and possibly a greater uptake of workers into the growing service sector, a subject of ongoing research. In conclusion, there is a delicate balance between livelihood potential, population size, welfare programs and environmental hazard mitigation that national planning has to carefully consider and which can be supported by integrative model simulations.

The results highlight the interlinked natural-socio-economic delta processes in action. Even though the results are illustrative, they are also robust. However, these still need to be used with care due to assumptions in the model setup. For example, there is an assumed land consolidation that might not happen in coastal Bangladesh, because land is an important safety net for agriculturally-dependent populations (Toufique and Turton 2002). Economic trends are also assumed and future changes are very uncertain especially under climate change and when flooding patterns significantly change (see Chapter 8). Thus, to inform policy, improved understanding of the basis for assumptions is needed, with a more robust scenario testing exercise, particularly as they may vary spatially and temporally. Changes outside coastal Bangladesh may also need to be considered. 


\subsection{Spatial Trade-Offs}

Trade-offs can also occur spatially. An example is shown in Fig. 10.3, which illustrates the flooding and socio-economic consequences of new polder development in coastal Bangladesh (Chapman et al. 2019). Under the current situation, the North-East part of the study area is regularly flooded in the monsoon season (Fig. 10.3a). Hence, the construction of new embankment and polders is proposed to reduce flooding and better manage water levels. However, hydrodynamic modelling shows that when these new polders are implemented, the neighbouring Western areas experience more extensive and deeper flooding (Fig. 10.3b). This is reflected in the decrease in agricultural output and increase in households in poverty for this area. However, these losses are significantly less than the gains experienced in the newly protected area, so there is a net benefit to Bangladesh. Although this does not include construction costs, it is clear that the economic benefits outweigh the damages; yet, significant livelihood and well-being changes can be expected in the neighbouring areas. The identification of this spatial trade-off allows consequences to be pro-actively managed, possibly with additional financial support to compensate for losses, new flood defence or training for new livelihoods.

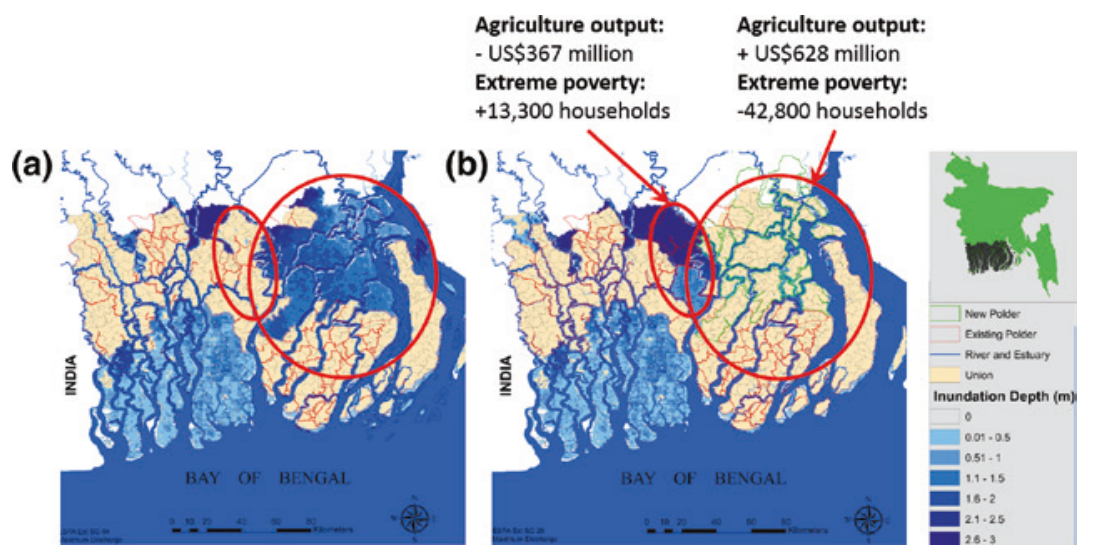

Fig. 10.3 Risk transfer due to new polders in coastal Bangladesh a existing polders and $\mathbf{b}$ existing with new South-Central polders (Adapted from Haque and Nicholls [2018] under CC BY 4.0) 
However, there are some other longer-term issues that need to be considered. For example, additional polders will increase the sediment deficit on the land (Chapter 5) resulting in accelerated subsidence and waterlogging. Also, the reduced flood risk will result in an increase in land value, and the poorest inhabitants might be forced off their land reducing their chance for an increased well-being. The social structure of these areas could therefore change due to these improvements and result in within-community conflicts. In addition, the poor who sell their land for short-term capital gain need to move elsewhere, potentially increasing the poverty rate and local issues (e.g. infrastructure overload) of the receiving area. In Bangladesh, the capital Dhaka is the main destination of such migration (Chapter 7).

\subsection{Household Adaptation Response to Change}

For policy development, in addition to identification of trade-offs such as those in Sect. 10.3, it is also beneficial to consider how the local population might respond to such changes at household level. As discussed in Chapters 7 and 9, people, and the households in which they reside, constantly adapt to changing natural and socio-economic conditions. This is a feature of life everywhere, but the high natural and social pressures in populous deltas accentuate these processes.

Based on analysis of household surveys in three deltas (see Chapters 2-4), an Integrated Bayesian Adaptation model is able to quantify the influence of different policy directions on household decision-making (Lázár et al. 2015). This model considers the characteristics of the household and the environment to quantify the possibility of the household to adapt its present behaviour.

Five broad categories of household adaptation options are simulated (Lázár et al. 2018a): 1. A financial change alters or supplements the household finances by getting a loan, insuring the livelihood activities and assets, applying for an NGO or government support or joining a cooperative; 2. A structural change can improve the house or make it climate resilient, trees might be planted around the house to provide 
shade, firewood or additional protection against wind damage, or the household might start using community shelters when disasters are imminent; 3. The household can modify or intensify the existing livelihood by start using fertiliser, irrigation, new productive assets and more tolerant crops, but it can also hire additional labour or participate in training courses; 4. Diversifying the existing livelihood might include growing a wider range of crops in multiple seasons, engaging for example in mixed farming/fishing activities, or enabling women to take up work outside the house; and finally, 5. the household might decide to send a household member away to alternate labour markets or for non-economic reasons such as family issues or education (i.e. migrate).

In this example, this Integrated Bayesian Adaptation model is used to simulate the effect of six plausible policy directions on household decisions. As discussed in (Suckall et al. 2018) and Sect. 9.5 of this book, these six plausible adaptation policy directions (APDs) were conceptualised representing contrasting governance contexts: A. Minimum Intervention (low investment/low commitment to policy change): no-regrets strategy where the lowest cost adaptation policies are pursued to protect citizens from some climate impacts; B. Capacity Expansion (high investment/low commitment to policy change) encourages climate-proof economic growth, but does not seek to make significant change to the current structure of the economy; C. Efficiency Enhancement (medium investment/medium commitment to policy change) is an ambitious strategy that promotes adaptation consistent with the most efficient management and exploitation of the current system, and best utilising ecosystem services to enhance livelihoods and well-being under climate change; D. System Restructuring (high investment/high commitment to change) embraces pre-emptive fundamental change at every level in order to completely transform the current social and ecological system: D1. Protect, broadly following the Dutch model with a high level of engineered protection, D2. Accommodate, live and work with nature principle, D3. Retreat population and infrastructural relocation.

Each of the above investment policy directions was broken down to a set of assumptions describing the changes of household and environmental characteristics as a result of the presence of APDs. During 
the model simulation, household and environmental characteristics are altered and the new adaptation choices are recorded. When comparing the baseline and new adaptation choices, the percent changes in household decisions can be quantified and compared (Fig. 10.4, N.B. the direction of the change can be positive or negative, and this is not shown). The most common adaptation responses for both maleand female-headed households are financial, where they seek alternative income sources, and structural, which is primarily emergency response to an environmental hazard. These broad trajectories indicate an improving household welfare.

Migration has limited appeal as an adaptation option with only female-headed households living in the Bangladeshi GBM and maleheaded in the Indian administered part of the GBM Delta (also termed the Indian Bengal Delta [IBD]), considering this as a viable option perhaps due to the higher level of protection and other social benefits. This indicates that, where possible, the general preference is for the population to remain in situ and adapt. The frequency of livelihood adaptations is also unlikely to increase in the future under these APDs. Overall, the results indicate that better policies can positively influence

\begin{tabular}{|l|c|c|c|c|}
\hline \multirow{2}{*}{ Male headed } & \multicolumn{2}{|c|}{ GBM } & \multirow{2}{*}{ Mahanadi } & \multirow{2}{*}{ Ghana } \\
\cline { 2 - 3 } & Bangladesh & IBD & & $*$ \\
\hline Financial & $* * *$ & $* * *$ & $* * *$ & $* *$ \\
\hline Structural & $* * *$ & $* * *$ & $* * *$ & $* *$ \\
\hline Intensify & $* *$ & $*$ & $* *$ & $*$ \\
\hline Diversify & $* *$ & $*$ & $*$ & $*$ \\
\hline Migrate & $*$ & $*$ & $*$ & $* *$ \\
\hline
\end{tabular}

\begin{tabular}{|l|c|c|c|c|}
\hline \multirow{2}{*}{$\begin{array}{c}\text { Female } \\
\text { headed }\end{array}$} & \multicolumn{2}{|c|}{ GBM } & \multirow{2}{*}{ Mahanadi } & \multirow{2}{*}{ Ghana } \\
\cline { 2 - 3 } & Bangladesh & IBD & & $*$ \\
\hline Financial & $* * *$ & $* * *$ & $* *$ & $*$ \\
\hline Structural & $* * *$ & $* * *$ & $* * *$ & $*$ \\
\hline Intensify & $*$ & $*$ & $*$ & $*$ \\
\hline Diversify & $*$ & $*$ & $*$ & $*$ \\
\hline Migrate & $* *$ & $*$ & $*$ & \\
\hline
\end{tabular}

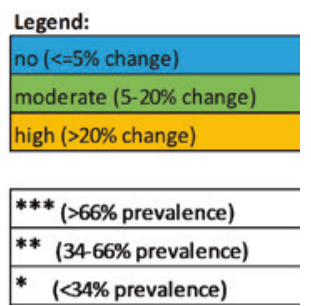

Fig. 10.4 Prevalence and the level of influence of adaptation policy directions on gendered household decisions in specified deltas 
in situ livelihoods and well-being, but migration trends are unlikely to be changed until there is a significant shift in well-being and as a result, the mindset of households changes significantly.

\subsection{Conclusion}

Natural deltas are complex systems with many interacting factors and that operate on diverse timescales, from seasons through to geological time. However, in the Anthropocene, human actions have become dominant and the complexity of delta system processes has grown significantly. As a consequence, the assessment of trade-offs and the balance between those that gain or lose are becoming highly important for policy development. Trade-offs between and within the socio-economic and natural systems are inevitable due to the competing interests and limited understanding of causal effects.

Deltas are key social and economic hubs and they are critical to the livelihoods and well-being of their resident and neighbouring populations. Deltas are also areas where any development is exposed to significant risks (Chapter 8) with environmental hazards growing due to climate change and other factors: submergence by sealevel rise is an obvious and widely discussed threat (see Chapter 6 and Wong et al. 2014, for example). Historical analogues might not be valid to infer the future due to feedbacks and system shifts. There is, therefore, a pressing need to understand the behaviour and co-evolution of the coupled human-natural systems and to simultaneously develop and manage these systems in ways that are positive for society while sustaining the environment. Integrated models can explore these interactions through policy and management options, identifying trade-offs and their possible consequences, an important contribution for key global policy goals such as the internationally-agreed Sustainable Development Goals (Hutton et al. 2018). They are also consistent with moves to adaptive delta planning such as the Bangladesh Delta Plan 2100.

The examples discussed in this chapter demonstrate how climate and environmental change is both an important driver and limiting 
factor for delta development. However, technological development and good governance can result in positive delta management. What kind of development is a choice for governments and associated decisionmakers. Economic growth is often the preferred objective, but this can result in higher segregation within communities, large scale environmental degradation and other ill-considered consequences. Effective balancing of trade-offs at basin level is enhanced by the existence of water resource management and flood management frameworks at this scale, and along with efficient data sharing arrangements, potentially lead to more enlightened delta management.

Actions of resident populations are crucial to the sustainability of future deltas; their relationship with the delta system, their use of resources and development of infrastructure inevitably influence environmental and livelihood potential changes and adaptation options. Thus, actions by individuals and households can either support or negate larger scale policy decisions. Combining the top-down policy influences with the bottom-up household actions is the way forward in integrated modelling of delta systems.

In many deltas, major investment in coastal protection provides only a short term fix to rising sea levels. Ultimately, all deltas will need to face the uncomfortable truth that any further large-scale infrastructure development will be highly costly, leading to potential lock-in and requiring continuous and substantial capital and maintenance funds. Thus, when planning for the long-term beyond the next 50 years, continuous adaptation at both national level (Haasnoot et al. 2013) and at local-scale in livelihood adaptation, investment in human capital, is more likely to secure long-term delta sustainability. Incorporating natural processes, such as space for river and tidal river management, holds high promises and should be prioritised wherever is possible in delta planning and management.

It is clear that managing coupled human and natural systems inevitably involves trade-offs, with winners and losers. There is no win-win situation for both delta systems and the use of its ecosystem services. Delta planning, thus, remains an intractable challenge with no easy solution. Looking to the future, these types of integrated analysis tools (e.g. $\triangle \mathrm{DIEM}$ ) provide new perspectives, hold great promise and also serve a fundamental and growing need. 


\section{References}

Allan, A. (2017). Legal aspects of flood management. In A. Rieu-Clarke, A. Allan, \& S. Hendry (Eds.), Routledge handbook of water law and policy. London, UK: Earthscan.

Amoako-Johnson, F., Hutton, C. W., Hornby, D., Lázár, A. N., \& Mukhopadhyay, A. (2016). Is shrimp farming a successful adaptation to salinity intrusion? A geospatial associative analysis of poverty in the populous Ganges-Brahmaputra-Meghna Delta of Bangladesh. Sustainability Science, 11(3), 423-439. https://doi.org/10.1007/s11625-016-0356-6.

Anderies, J. M., Rodriguez, A. A., Janssen, M. A., \& Cifdaloz, O. (2007). Panaceas, uncertainty, and the robust control framework in sustainability science. Proceedings of the National Academy of Sciences, 104(39), 15194 15199. https://doi.org/10.1073/pnas.0702655104.

APFM. (2006). Legal and institutional aspects of integrated flood management (APFM Technical Document No. 2). Associated Program on Flood Management, World Meteorological Organization, Geneva, Switzerland.

BBS. (2011). Report of the household income and expenditure survey 2010. Bangladesh Bureau of Statistics (BBS), Ministry of Planning, Government of the People's Republic of Bangladesh, Dhaka, Bangladesh. http://203.112.218.65:8008/WebTestApplication/userfiles/Image/Latest Reports/HIES-10.pdf. Last accessed 12 November 2018.

Chapman, A., \& Darby, S. (2016). Evaluating sustainable adaptation strategies for vulnerable mega-deltas using system dynamics modelling: Rice agriculture in the Mekong Delta's An Giang Province, Vietnam. Science of the Total Environment, 559, 326-338. https://doi.org/10.1016/j. scitotenv.2016.02.162.

Chapman, A., Noman, M. Z. N., Lázár, A. N., Nicholls, J. R., Haque, A., Hussain, M. M., et al. (2019). Supporting adaptation and development policy making in deltas: Application of an integrated assessment model in coastal Bangladesh. Journal of Environmental Planning and Management (in review).

Daw, T., Brown, K., Rosendo, S., \& Pomeroy, R. (2011). Applying the ecosystem services concept to poverty alleviation: The need to disaggregate human well-being. Environmental Conservation, 38(4), 370-379. https:// doi.org/10.1017/S0376892911000506.

Daw, T. M., Hicks, C. C., Brown, K., Chaigneau, T., Januchowski-Hartley, F. A., Cheung, W. W. L., et al. (2016). Elasticity in ecosystem services: 
Exploring the variable relationship between ecosystems and human wellbeing. Ecology and Society, 21, 2. https://doi.org/10.5751/ES-08173-210211. Day, J. W., Agboola, J., Chen, Z., D’Elia, C., Forbes, D. L., Giosan, L., et al. (2016). Approaches to defining deltaic sustainability in the 21 st century. Estuarine, Coastal and Shelf Science, 183, 275-291. https://doi. org/10.1016/j.ecss.2016.06.018.

European Parliament and Council. (2000). Water Framework Directive (2000/60/EC). Official Journal of the European Communities.

Gerlak, A. K., Lautze, J., \& Giordano, M. (2011). Water resources data and information exchange in transboundary water treaties. International Environmental Agreements: Politics, Law and Economics, 11(2), 179-199. https://doi.org/10.1007/s10784-010-9144-4.

Global Water Partnership. (2000). Integrated water resources management (TAC Background Paper 4). Stockholm, Sweden: Global Water Partnership. https://www.gwp.org/globalassets/global/toolbox/publications/background-papers/04-integrated-water-resources-management-2000-english. pdf. Last accessed 12 November 2018.

Haasnoot, M., Kwakkel, J. H., Walker, W. E., \& ter Maat, J. (2013). Dynamic adaptive policy pathways: A method for crafting robust decisions for a deeply uncertain world. Global Environmental Change, 23(2), 485-498. https://doi.org/10.1016/j.gloenvcha.2012.12.006.

Haque, A., \& Nicholls, R. J. (2018), Floods and the Ganges-BrahmaputraMeghna Delta. In R. J. Nicholls, C. W. Hutton, W. N. Adger, S. E. Hanson, M. M. Rahman, \& M. Salehin (Eds.), Ecosystem services for well-being in deltas: Integrated assessment for policy analysis (pp. 147-159). Cham: Springer. http://dx.doi.org/10.1007/978-3-319-71093-8_8.

Hoegh-Guldberg, O., Jacob, D., \& Taylor, M. (2018). Impacts of $1.5^{\circ} \mathrm{C}$ global warming on natural and human systems. In Global warming of $1.5^{\circ} \mathrm{C}$ - An IPCC special report on the impacts of global warming of $1.5^{\circ} \mathrm{C}$ above pre-industrial levels and related global greenhouse gas emission pathways, in the context of strengthening the global response to the threat of climate change, sustainable development, and efforts to eradicate poverty (246 pp.). Incheon, Republic of Korea: Intergovernmental Panel on Climate Change (IPCC). http://report.ipcc.ch/sr15/pdf/sr15_chapter3.pdf. Last accessed 13 November 2018.

Hutton, C. W., Nicholls, R. J., Lázár, A. N., Chapman, A., Schaafsma, M., \& Salehin, M. (2018). Potential trade-offs between the Sustainable Development Goals in coastal Bangladesh. Sustainability, 10(4), 1008. http://dx.doi.org/10.3390/su10041108. 
Lázár, A. N., Nicholls, R. J., Payo, A., Adams, H., Mortreux, C., Suckall, N., et al. (2015). A method to assess migration and adaptation in deltas: A preliminary fast-track assessment (Deltas, Vulnerability and Climate Change: Migration and Adaptation [DECCMA] Working Paper). Southampton, UK: DECCMA Consortium. https://generic.wordpress.soton.ac.uk/deccma/resources/working-papers/. Last accessed 3 September 2018.

Lázár, A. N., Adams, H., de Campos, R. S., Vincent, K., Nicholls, J. R., \& Adger, W. N. (2018a). How gender affects household decisions to adapt or migrate due to environmental risk: A Bayesian network model for coastal Bangladesh (DECCMA Working Paper). Deltas, Vulnerability and Climate Change: Migration and Adaptation, IDRC Project Number 107642.

Lázár, A. N., Payo, A., Adams, H., Ahmed, A., Allan, A., Akanda, et al. (2018b). Integrative analysis applying the delta dynamic integrated emulator model in south-west coastal Bangladesh. In R. J. Nicholls, C. W. Hutton, W. N. Adger, S. Hanson, M. M. Rahman, \& M. Salehin (Eds.), Ecosystem services for well-being in deltas: Integrated assessment for policy analysis. Cham, Switzerland: Springer. http://dx.doi.org/10.1007/978-3-31971093-8_28.

Nicholls, R. J., Hutton, C., Adger, W. N., Hanson, S. E., Rahman, M. M., \& Salehin, M. (Eds.). (2018). Ecosystem services for well-being in deltas: Integrated assessment for policy analysis. London, UK: Palgrave Macmillan.

Nicholls, R. J., Hutton, C. W., Lázár, A. N., Allan, A., Adger, W. N., Adams, H., et al. (2016). Integrated assessment of social and environmental sustainability dynamics in the Ganges-Brahmaputra-Meghna Delta, Bangladesh. Estuarine and Coastal Shelf Science, 183, 370-381. https://doi. org/10.1016/j.ecss.2016.08.017.

Overeem, I., \& Syvitski, J. P. M. (2009). Dynamics and vulnerability of delta systems (LOICZ Reports and Studies 35). Geesthacht, Germany: GKSS Research Center.

Paavola, J., Gouldson, A., \& Kulvankova-Oravska, T. (2009). Interplay of actors, scales, frameworks and regimes in the governance of biodiversity. Environmental Policy and Governance, 19(3), 148-158. http://dx.doi. org/10.1002/eet.505.

Ramsar. (1971, January 30-February 3). The final act of the international conference on conservation of wetlands and waterfowl. Ramsar, Iran.

Seijger, C., Douven, W., van Halsema, G., Hermans, L., Evers, J., Phi, H. L., et al. (2017). An analytical framework for strategic delta planning: Negotiating consent for long-term sustainable delta development. Journal of 
Environmental Planning and Management, 60(8), 1485-1509. https://doi. org/10.1080/09640568.2016.1231667.

Steffan-Dewenter, I., Kessler, M., Barkmann, J., Bos, M. M., Buchori, D., Erasmi, S., et al. (2007). Tradeoffs between income, biodiversity, and ecosystem functioning during tropical rainforest conversion and agroforestry intensification. Proceedings of the National Academy of Sciences, 104(12), 4973-4978. https://doi.org/10.1073/pnas.0608409104.

Suckall, N., Tompkins, E. L., Nicholls, R. J., Kebede, A. S., Lázár, A. N., Hutton, C., et al. (2018). A framework for identifying and selecting long term adaptation policy directions for deltas. Science of the Total Environment, 633, 946-957. https://doi.org/10.1016/j.scitotenv.2018.03.234.

Toufique, K. A., \& Turton, C. (2002). Hands not land: How livelihoods are changing in rural Bangladesh. Dhaka, Bangladesh: Bangladesh Institute of Development Studies.

UNECE. (1998). Convention on access to information, public participation in decision-making and access to justice in environmental matters (Aarhus Convention). Aarhus, Denmark, 25 June 1998, entered into force 2001. http://www.unece.org/fileadmin/DAM/env/pp/documents/cep43e.pdf.

United Nations. (1966). International covenant on economic social and cultural rights.

United Nations. (1997). Convention on the law of the non-navigational uses of international watercourses on the 21 May 1997, entered into force 17 August 2014.

United Nations. (2015). Sendai framework for disaster risk reduction 2015-2030.

Wolman, M. G., \& Gerson, R. (1978). Relative scales of time and effectiveness of climate in watershed geomorphology. Earth Surface Processes, 3(2), 189-208. https://doi.org/10.1002/esp.3290030207.

Wong, P. P., Losada, I. J., Gattuso, J.-P., Hinkel, J., Khattabi, A., McInnes, K. L., et al. (2014). Coastal systems and low-lying areas. In C. B. Field, V. R. Barros, D. J. Dokken, K. J. Mach, M. D. Mastrandrea, T. E. Bilir, et al. (Eds.), Climate change 2014: Impacts, adaptation, and vulnerability. Part A: Global and sectoral aspects (pp. 361-409). Contribution of Working Group II to the Fifth Assessment Report of the Intergovernmental Panel on Climate Change. Cambridge, UK and New York, NY: Cambridge University Press. 
Open Access This chapter is licensed under the terms of the Creative Commons Attribution 4.0 International License (http://creativecommons. org/licenses/by/4.0/), which permits use, sharing, adaptation, distribution and reproduction in any medium or format, as long as you give appropriate credit to the original author(s) and the source, provide a link to the Creative Commons license and indicate if changes were made.

The images or other third party material in this chapter are included in the chapter's Creative Commons license, unless indicated otherwise in a credit line to the material. If material is not included in the chapter's Creative Commons license and your intended use is not permitted by statutory regulation or exceeds the permitted use, you will need to obtain permission directly from the copyright holder. 